\title{
Dietary linoleic acid elevates endogenous 2-arachidonoylglycerol and anandamide in Atlantic salmon (Salmo salar L.) and mice, and induces weight gain and inflammation in mice
}

\author{
Anita R. Alvheim ${ }^{1,2}$, Bente E. Torstensen ${ }^{1}$, Yu Hong Lin $^{3}$, Haldis H. Lillefosse ${ }^{1,4}$, Erik-Jan Lock ${ }^{1}$, \\ Lise Madsen $^{1,4}$, Joseph R. Hibbeln ${ }^{3}$ and Marian K. Malde ${ }^{1 *}$ \\ ${ }^{1}$ National Institute of Nutrition and Seafood Research (NIFES), PO Box 2029, Nordnes, 5817 Bergen, Norway \\ ${ }^{2}$ Department of Biomedicine, University of Bergen, Bergen, Norway \\ ${ }^{3}$ National Institute on Alcohol Abuse and Alcoholism, 5625 Fishers Lane, Rockville, MD 20852, USA \\ ${ }^{4}$ Department of Biology, University of Copenhagen, Copenhagen, Denmark
}

(Submitted 25 January 2012 - Final revision received 23 May 2012 - Accepted 4 July 2012 - First published online 10 August 2012)

\begin{abstract}
Dietary intake of linoleic acid (LA) has increased dramatically during the twentieth century and is associated with a greater prevalence of obesity. Vegetable oils are recognised as suitable alternatives to fish oil (FO) in feed for Atlantic salmon (Salmo salar L.) but introduce high amounts of LA in the salmon fillet. The effect on fish consumers of such a replacement remains to be elucidated. Here, we investigate the effect of excessive dietary LA from soyabean oil (SO) on endocannabinoid levels in Atlantic salmon and mice, and study the metabolic effects in mice when SO replaces FO in feed for Atlantic salmon. Atlantic salmon were fed FO and SO for 6 months, and the salmon fillet was used to produce feed for mice. Male C57BL/6J mice were fed diets of $35 \%$ of energy as fat based on FO- and SO-enriched salmon for 16 weeks. We found that replacing FO with SO in feed for Atlantic salmon increased LA, arachidonic acid (AA), decreased EPA and DHA, elevated the endocannabinoids 2-arachidonoylglycerol (2-AG) and anandamide (AEA), and increased TAG accumulation in the salmon liver. In mice, the SO salmon diet increased LA and AA and decreased EPA and DHA in the liver and erythrocyte phospholipids, and elevated 2-AG and AEA associated with increased feed efficiency, weight gain and adipose tissue inflammation compared with mice fed the FO salmon diet. In conclusion, excessive dietary LA elevates endocannabinoids in the liver of salmon and mice, and increases weight gain and counteracts the anti-inflammatory properties of EPA and DHA in mice.
\end{abstract}

Key words: Linoleic acid: 2-Arachidonoylglycerol: Anandamide: Obesity: Inflammation: Atlantic salmon

Dietary advice to replace saturated fat with PUFA to reduce the incidence of $\mathrm{CVD}^{(1,2)}$, and increasing use of vegetable oils, have led to a dramatic increase in the human consumption of linoleic acid (LA, 18:2n-6) during the twentieth century ${ }^{(3)}$. The estimated per capita consumption of soyabean oil, one of the major dietary sources of LA in the USA, has increased more than 1000-fold from 1909 to 1999, increasing the availability of LA from $2 \cdot 8$ to $7 \cdot 2 \%$ of energy $(\mathrm{en} \%)^{(3)}$. Dietary intakes of $n-3$ and $n-6$ fatty acids are critical determinants of tissue proportions of bioactive 20- and 22-carbon $n-3$ and n-6 highly unsaturated fatty acids. The tissue fatty acid composition reflects dietary PUFA intake since 18-carbon $n-3$ and n-6 fatty acids cannot be synthesised de novo ${ }^{(4)}$. The endocannabinoids 2-arachidonoylglycerol (2-AG) and anandamide (AEA) are endogenous lipid mediators formed from the pool of arachidonic acid (AA) in membrane phospholipids (AA-PL). Hence, endocannabinoid activity can be altered by dietary fatty acids that in turn affect endocannabinoid precursor levels after a short term ${ }^{(5,6)}$ or prolonged feeding ${ }^{(7-10)}$. Dietary $\mathrm{LA}^{(10)}$ and $\mathrm{AA}^{(5,7,11)}$ increased, whereas dietary $n-3$ PUFA ${ }^{(5,6,10,12-15)}$, decreased $2-A G$ and AEA. The activation of the cannabinoid receptor 1 by endocannabinoids or exogenous agonists, centrally and peripherally, favours metabolic processes that stimulate appetite, increase food intake, activate fat storage pathways and down-regulate catabolism resulting in adipose accumulation $(8,10,16)$.

The type of fat, specifically the imbalance in $n-6$ to $n-3$ PUFA, is emerging as a risk factor for developing obesity $^{(17-20,7)}$. Dietary LA have been shown to have adipogenic properties in both humans ${ }^{(21)}$ and rodents ${ }^{(18,19,22-25)}$.

Abbreviations: AA, arachidonic acid; AEA, anandamide; AG, arachidonoylglycerol; en\%, percentage of energy; eWAT, epididymal white adipose tissue; FO, fish oil; iWAT, inguinal white adipose tissue; LA, linoleic acid; PL, phospholipids; SO, soyabean oil; SREBP-1c, sterol regulatory element binding protein-1c. 
Fish oils rich in EPA and DHA limit diet-induced obesity in rodents ${ }^{(26,27)}$ and are associated with weight reduction in humans ${ }^{(28-30)}$. We have previously shown a robust positive correlation between the consumption of soyabean oil, the major contributor to dietary LA, and obesity in human subjects $^{(10)}$. When investigating these human dietary changes over the last century in an animal model, we have demonstrated that it is the $n-3$ and $n-6$ fat composition of the diets, rather than the total amount of fat, that determined the obesogenic properties of a diet ${ }^{(10)}$. High-fat diets $(60 \mathrm{en} \%)$ commonly used to induce obesity typically utilise soyabean oil and contain high levels of LA. Such diets elevate endocannabinoid levels in tissues involved in energy homeostasis contributing to diet-induced obesity in mice after long-term feeding $^{(7,8)}$. We have recently reversed the obesogenic effect of high-fat isoenergetic diets by decreasing dietary LA from 8 to $1 \mathrm{en} \%$ and attenuated the AA-dependent excessive endocannabinoid activity ${ }^{(10)}$. Furthermore, we have demonstrated that reducing the AA-PL precursor pool by adding $1 \mathrm{en} \%$ EPA and DHA to 8 en $\%$ LA diets reversed both the stimulation of endocannabinoid activity and the obesogenic effect of highfat diets ${ }^{(10)}$. Reducing excessive endocannabinoid system activity is actively being pursued to reduce obesity ${ }^{(8)}$. The pharmacological blockade of the cannabinoid receptor 1 is effective in treating obesity and related metabolic derangements ${ }^{(31,32)}$. However, serious psychiatric side effects caused the withdrawal of rimonabant, a selective cannabinoid receptor 1 antagonist ${ }^{(33,34)}$. Thus, there is a definite need for a dietary approach to reduce substrate availability for endocannabinoid synthesis.

The high degree of conservation of endocannabinoid system components ${ }^{(35)}$ and the presence of the cannabinergic system in most animal systems ${ }^{(36-40)}$ point out the importance of the endocannabinoid system in the regulation of basic physiological responses such as energy homeostasis and feeding behaviour ${ }^{(36-38,41,42)}$. Farmed Atlantic salmon have traditionally been fed diets based on fish oil and fishmeal, thus being recognised as a rich source of the marine $n-3$ fatty acids EPA and DHA. The steady increase in aquaculture production volume of $8-10 \%$ per year ${ }^{(43)}$ has resulted in the increased use of alternative proteins and oils in aqua feeds. Vegetable oils are recognised as suitable alternatives to fish oils ${ }^{(44,45)}$, although they are devoid of EPA and DHA, with high levels of LA and monounsaturates, thereby reducing EPA and DHA and increasing LA content of fish fillet ${ }^{(44-46)}$. The current fish oil replacement levels in aqua feeds are approximately 50\%, resulting in approximately $2 \mathrm{~g}$ $\mathrm{EPA}+\mathrm{DHA} / 100 \mathrm{~g}$ salmon flesh (www.nifes.no). This fish oil replacement level is expected to increase in future aquaculture feeds as Atlantic salmon production volumes increase ${ }^{(43)}$ whereas global availability of fish oil remains constant (www.iffo.net). However, there is a lack of documentation of the health consequences of replacing fish oil with vegetable oil in feed for Atlantic salmon in fish consumers. We here posit that excessive dietary LA elevates endocannabinoid activity in salmon and mice, with a concomitant increase in adiposity in mice fed LA-enriched salmon.

\section{Methods}

\section{Feeding experiment in Atlantic salmon}

Ethical statement. The experiments complied with the guidelines of the Norwegian Regulation on Animal Experimentation and EC Directive 86/609/EEC. The protocol was approved by local authorities at the Institute of Marine Research (Bergen, Norway) and the National Animal Research Authority.

Animals. Atlantic salmon (initial weight 340 (SEM 17) g ( $n$ 55)) were randomly distributed to six fibreglass tanks $(1.5 \times 1.5 \times 0.9 \mathrm{~m}$, water depth $0.6 \mathrm{~m})$ provided with a continuous flow of seawater maintaining an average salinity of $35 \%$, an average temperature $8^{\circ} \mathrm{C}$ and a $12 \mathrm{~h}$ light-dark cycle. Mortality was recorded daily. The feeding trial was carried out at the Matre Aquaculture Research Station (Matredal, Norway; $60^{\circ} 52^{\prime} \mathrm{N}, 05^{\circ} 35^{\prime} \mathrm{E}$ ) from 28 April 2008 to 6 October 2008.

Diets. Experimental diets (EWOS Innovation) provided as pellets were fed ad libitum to triplicate tanks per dietary treatment for 6 months. The diets contained the same $6 \mathrm{~mm}$ base pellet and were supplemented with either cleaned fish oil (FO; FF Skagen) or refined soyabean oil (SO; Mills) (Table 1) to ensure negligible amounts of contaminants such as persistent organic pollutants and polyaromatic hydrocarbons.

Sampling. Fish were feed-deprived $24 \mathrm{~h}$ before killing. From each tank, six fish were randomly sampled and killed

Table 1. Nutrient composition of mice and salmon diets

\begin{tabular}{|c|c|c|c|c|}
\hline & \multicolumn{2}{|c|}{ Mice diets } & \multicolumn{2}{|c|}{$\begin{array}{c}\text { Salmon } \\
\text { diets }\end{array}$} \\
\hline & $\mathrm{FO}$ & SO & $\mathrm{FO}$ & SO \\
\hline \multicolumn{5}{|l|}{ Dietary oils (g/kg) } \\
\hline Fish oil & - & - & 250 & - \\
\hline Soyabean oil & - & - & - & 250 \\
\hline Cocoa & 84 & 38 & & \\
\hline Safflower oil & - & 7 & & \\
\hline Olive oil & 13 & 18 & & \\
\hline Flaxseed oil & 2 & 2 & & \\
\hline Fat from salmon fillet & 66 & 101 & & \\
\hline Total oil added & 99 & 65 & 250 & 250 \\
\hline \multicolumn{5}{|l|}{ Energy (en\%) derived from } \\
\hline Fat & 35 & 32 & 51 & 51 \\
\hline Carbohydrate & 44 & 47 & 11 & 12 \\
\hline Protein & 21 & 21 & 36 & 35 \\
\hline Energy (kJ) & 19 & 19 & 24 & 24 \\
\hline \multicolumn{5}{|l|}{ Dietary fatty acid profile (en\%) } \\
\hline Sum SFA & 17 & 14 & 11 & 7 \\
\hline Sum MUFA & 10 & 9 & 20 & 12 \\
\hline $18: 2 n-6$ & 1 & 8 & 1.5 & 21 \\
\hline $20: 4 n-6$ & 0.06 & 0.07 & 0.3 & - \\
\hline Sum $n-6$ & 1 & 9 & 2 & 21 \\
\hline $18: 3 n-3$ & 0.4 & 1 & 1 & 3 \\
\hline $20: 5 n-3$ & $1 \cdot 0$ & 0.5 & 3.5 & 0.5 \\
\hline $22: 6 n-3$ & 1.7 & $1 \cdot 3$ & $3 \cdot 8$ & 0.9 \\
\hline Sum $n-3$ & 4 & 3 & 11 & 4 \\
\hline Total $n-6: n-3$ ratio & 0.3 & 3 & $0 \cdot 2$ & 5 \\
\hline Estimated $n-6$ HUFA* (\%) & 8 & 33 & 13 & 51 \\
\hline Estimated omega-3 index† & 26 & 18 & 24 & 12 \\
\hline
\end{tabular}

FO, fish oil; SO soyabean oil; en\%, percentage of energy; HUFA, highly unsaturated fatty acids.

${ }^{*}$ Calculated from the Lands equation ${ }^{(4)}:(20: 3 n-6+20: 4 n-6+22: 5 n-6) /$ $(20: 3 n-6+20: 4 n-6+22: 5 n-6+20: 5 n-3+22: 5 n-3+22: 6 n-3) \times 100$. †Calculated from $(n-3$ HUFA $\times 0.32)-3.5$ based on Harris \& von Schacky ${ }^{(69)}$ and Lands ${ }^{(70)}$. 
with a sharp blow to the head to ensure no contamination of anaesthetics in the fish fillet. Body weight and length were measured, blood was collected and liver was quickly snapfrozen in liquid $\mathrm{N}_{2}$ and stored at $-80^{\circ} \mathrm{C}$ until further analysis. The fillets were collected for use in mice feed.

Lipid extraction and fatty acid analysis. Total lipid was extracted from the Atlantic salmon diets, liver and fillets by homogenisation in chloroform-methanol (2:1, v/v) with 19: 0 methyl ester as the internal standard. Fatty acid methyl esters (FAME) were prepared from total lipid by $\mathrm{BF}_{3}$ following saponification, as described previously ${ }^{(47,48)}$. Lipid classes of salmon liver were determined essentially as described by Jordal et al. ${ }^{(49)}$ based on Bell et al. ${ }^{(50)}$.

\section{Feeding experiment in C57BL/6J mice}

Ethical statement. The mouse experiment was approved by the National Animal Health Authorities (Norwegian approval identification 1973). Care and handling were in accordance with local institutional recommendations and rules, and no adverse events were observed. Mice were anaesthetised with isoflurane to minimise suffering before decapitation.

Animals. Male mice, 6 weeks of age (C57BL/6J, Taconic) were randomly assigned to the experimental diets (Table 1) and housed individually. Mice were maintained on a $12 \mathrm{~h}$ light-dark cycle at $28 \pm 1^{\circ} \mathrm{C}$.

Diets. Feed provided as pellets were available ad libitum for 16 weeks. The diets contained the same amount $(\mathrm{g} / \mathrm{kg})$ of sucrose 50, cellulose 50, maize starch 100, mineral mix (American Institute of Nutrition (AIN) 93M MX) 47, vitamin mix (AIN $93 \mathrm{VX}$ ) 13, L-cysteine 3, choline bitartrate 2.5, and ethoxyquin 0.06. Salmon fillets were freeze-dried, ground and mixed with the other ingredients to make pellets. The salmon fillets were the sole protein source and provided $20 \mathrm{en} \%$ proteins, and 40 and $60 \mathrm{en} \%$ fat for FO- and SOenriched salmon, respectively, due to higher fat content in the SO salmon fillets (Table 1). The fat contents of the salmon fillets were $26 \mathrm{~g} / 100 \mathrm{~g}$ FO fillet and $33 \mathrm{~g} / 100 \mathrm{~g}$ SO fillet. Additional vegetable oils were added to obtain a total lipid content of $35 \mathrm{en} \%$. A mix of oils was used to preserve the fatty acid profile of the salmon fillets (FO and SO) regarding LA, $\alpha$-linolenic acid (18:3n-3) and MUFA with reciprocal changes in SFA (Table 1). The full fatty acid profile of the salmon fillets and vegetable oils is given in Table S1 (available online). Feed intake was measured daily by weighing each food cup and spillage and subtracting the previously collected weight. Body weight was recorded once per week for all mice.

Endocannabinoids. Brain and liver were quickly snapfrozen in liquid $\mathrm{N}_{2}$. AEA and 2-AG were extracted and analysed by GC-MS/MS as described previously by Alvheim et $a{ }^{(10)}$ in the mouse liver and cerebral cortex, and the salmon liver.

Phospholipid fatty acid profile. Liver, erythrocyte and adipose tissue lipids were extracted with chloroform-methanol $(2: 1, \mathrm{v} / \mathrm{v})$ and PL were separated from neutral lipids by solid-phase extraction. Liver and epididymal white adipose tissue (eWAT) lipids were evaporated to dryness and recovered in chloroform to a concentration of $50 \mathrm{mg} / \mathrm{ml}$ lipids. An aliquot of $200 \mu \mathrm{l}$ ( $10 \mathrm{mg}$ lipids) was applied to a solid-phase extraction column (Isolute; Biotage). Erythrocyte lipids were evaporated to dryness and recovered with three washings of $100 \mathrm{ml}$ chloroform and deposited to the solid-phase extraction column. Neutral lipids were eluted with $10 \mathrm{ml}$ chloroformmethanol (98:2, v/v) and polar lipids were eluted with $20 \mathrm{ml}$ methanol. The fatty acid composition in the phospholipid fraction of liver and erythrocytes, and the neutral fraction of adipose tissue were analysed by GC as described previously $^{(47,48)}$

Blood chemistry. Blood was collected at the time of killing and separated into erythrocytes and plasma. Plasma hormone levels were determined using commercially available ELISA kits in accordance with the manufacturer's instructions for insulin (Ultrasensitive ELISA, mouse; DRG Instruments $\mathrm{GmbH}$ ), leptin (Leptin (Mouse/Rat) ELISA; ALPCO Immunoassays) and adiponectin (Adiponectin (Mouse) Total, HMW ELISA; ALPCO Immunoassays).

Histology. Sections of eWAT and inguinal white adipose tissue (iWAT) were fixed in $4 \%$ formaldehyde in $0 \cdot 1 \mathrm{M}$-phosphate buffer for $24 \mathrm{~h}$, washed in phosphate buffer, dehydrated in ethanol, and embedded in paraffin after clearing with xylene. Then, $5 \mu \mathrm{m}$-thick sections of the embedded tissue were stained with eosin and haematoxylin. The sections were visually examined using an Olympus BX 51 binocular microscope (Olympus) fitted with a Nikon DS-Fi1 camera (Digital Sight DS-Fi1; Nikon). Adipocyte size was measured using the interactive measurement module of an image analysis system equipped with an Olympus microscope (Olympus), a Nikon camera and NIS-elements software (Nikon). Thereafter, 200 adipocytes per tissue were randomly selected
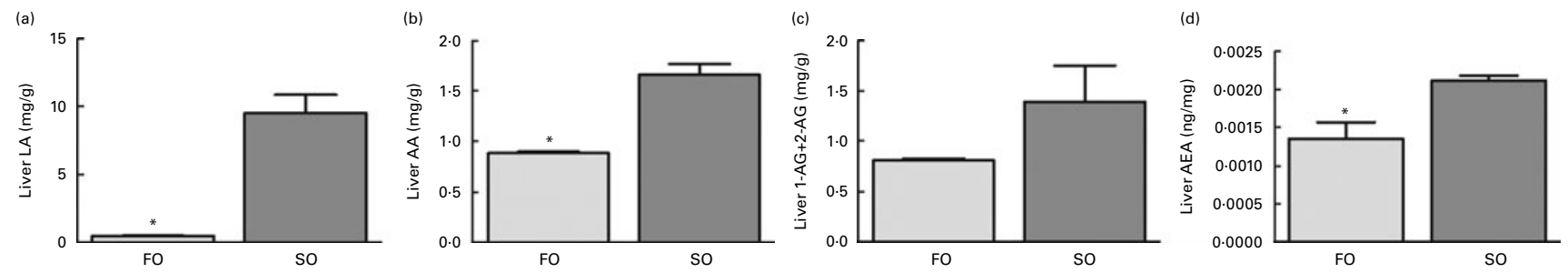

Fig. 1. Levels of the $n-6$ fatty acids (a) linoleic acid (LA) and (b) arachidonic acid (AA), and the endocannabinoids (c) 2-arachidonoylglycerol (AG) and (d) anandamide (AEA) in the liver of Atlantic salmon fed soyabean oil (SO, $\square$ ) and fish oil (FO, $\square)$. Values are means, with their standard errors represented by vertical bars. ${ }^{*}$ Mean values were significantly different from those of SO-fed salmon $(P<0.05)$. 
Table 2. Physical parameters in Atlantic salmon fed fish oil (FO) or soyabean oil (SO)

(Mean values with their standard errors, $n 3$ from pooled samples)

\begin{tabular}{|c|c|c|c|c|}
\hline \multirow[b]{2}{*}{ Parameters } & \multicolumn{2}{|c|}{ FO } & \multicolumn{2}{|c|}{ so } \\
\hline & Mean & SEM & Mean & \\
\hline Initial body weight (g) & 340 & 17 & 340 & 17 \\
\hline Final body weight (g) & 1165 & 38 & 1033 & 48 \\
\hline Minimum-maximum body weight $†$ & \multicolumn{2}{|c|}{ 862-1639 } & \multicolumn{2}{|c|}{$820-1624$} \\
\hline Final body length $(\mathrm{cm})$ & 44 & 0 & 43 & \\
\hline WAT + inner organs $\ddagger \S(g)$ & 104 & 4 & 82 & 4 \\
\hline Visceral somatic index† (\%) & 8.9 & 0.2 & 7.9 & 0.2 \\
\hline Total fish lipid (\%) & $15 \cdot 2$ & $0 \cdot 1$ & $13 \cdot 9$ & 0.0 \\
\hline Total fish protein (\%) & $17 \cdot 3$ & 0.6 & $17 \cdot 0$ & 0.3 \\
\hline Water $(\%)$ & 68 & 1 & 69 & 1 \\
\hline Hepatosomatic index $¥ \|(\%)$ & 1.5 & 0.0 & 1.4 & 0.0 \\
\hline Liver TAG $(\mathrm{mg} / \mathrm{g})$ & $4 \cdot 7^{\star}$ & 1.3 & $12 \cdot 5$ & $2 \cdot 1$ \\
\hline Liver PL (mg/g) & 50 & 1 & 52 & 1 \\
\hline Liver total lipids (mg/g) & $61^{*}$ & 2 & 72 & 3 \\
\hline
\end{tabular}

WAT, white adipose tissue; PL, phospholipids.

Mean value was significantly different from that of SO-fed salmon: ${ }^{*} P<0.04$ (Student's independent $t$ test).

†Pooled samples; nine fish per tank, three tanks.

$\ddagger$ Pooled samples; six fish per tank, three tanks.

§Includes intestine, stomach and spleen.

II Hepatosomatic index: (liver weight $(\mathrm{g}) /$ body weight $(\mathrm{g})) \times 100$.

and measured by drawing a horizontal line between the cell membranes.

Immunohistochemistry. To distinguish macrophages from other cell types in the adipose tissue, the presence of F4/80, a transmembrane protein specific for macrophages, was visualised by immunohistochemistry. Samples were processed as described previously. In brief, $5 \mu \mathrm{m}$ sections were deparafinised, rehydrated and endogenous peroxide was inactivated $\left(3 \% \mathrm{H}_{2} \mathrm{O}_{2}\right)$. To reduce non-specific staining, the sections were incubated in heat-inactivated normal goat serum $(10 \%$, $10 \mathrm{~min})$. The sections were then incubated overnight at $4{ }^{\circ} \mathrm{C}$ with rat anti-mouse $\mathrm{F} 4 / 80$ (1:500; Serotec), subsequently washed in Tris-buffered saline (three times, $10 \mathrm{~min}$ ) and incubated with horseradish peroxidase-conjugated rat anti-goat $\operatorname{IgG}(1: 250$; Serotec) for $2 \mathrm{~h}$. After washing in Tris-buffered saline (three times, $10 \mathrm{~min}$ ), specific binding of the antibody to macrophages was visualised using diaminobenzidine. The relative abundance of macrophages compared with fat cells was assessed by a scientist unaware of the experimental protocol.
Statistics. All data were analysed using STATISTICA (data analysis software system), version 9.0 (StatSoft, Inc.). Levene's test was used to test for homogeneity of variance. Data were analysed with Student's independent $t$ test with a significance level of $P<0 \cdot 05$. Weekly body weight was measured by repeated-measures ANOVA and a statistical trend was set at $P<0.08$. Data are presented as means with their standard errors. Samples of the liver and fillet of salmon were pooled-three to nine fish per tank in each of the three tanks to provide three fish from pooled samples. Mouse samples represent nine individual animals.

\section{Results \\ Effect of the experimental diets in Atlantic salmon}

Replacing dietary FO with SO resulted in a 19-fold increase in LA, significantly higher AA levels and nearly doubled the concentration of 2-AG (Fig. 1) in the salmon liver. There was no difference in final body weight, mean visceral somatic index ((visceral adipose tissue + internal organ)/body weight) or whole-fish proximate composition after 6 months of feeding (Table 2). However, fish fed the SO diet had significantly higher amounts of TAG and total lipid in the liver than fish fed the FO diet, with no difference in PL (Table 2). Feeding SO to Atlantic salmon increased fillet LA (530\%) and reduced EPA (71\%) and DHA (56\%) compared with fillets from Atlantic salmon fed FO (Table 3).

\section{Effect of the experimental diets in mice}

Mice fed the SO salmon diet had higher amounts of LA and AA in the liver PL (Fig. 2(a) and (b)), erythrocyte-PL and neutral lipids of eWAT than mice fed the FO salmon diet (Table 4). Increasing dietary LA by replacing FO with SO in feed for Atlantic salmon significantly elevated liver 2-AG, elevated brain 2-AG and AEA, and significantly increased weight gain, feed efficiency and caused higher body weight $(P<0.08)$ in mice (Fig. 2). Mice fed the SO salmon diet had higher body weight than mice fed the FO salmon diet from week 6 , but the trend was only significant from week 9 $(P=0.05-P<0.07)$ with a significant difference in week 15 $(P=0 \cdot 03)$. Energy intake and plasma concentrations of

Table 3. $n-6$ and $n-3$ profile in total lipids of fillet and liver of Atlantic salmon fed fish oil (FO) and soyabean oil (SO)

(Mean values with their standard errors, $n 3$ from pooled samples)

\begin{tabular}{|c|c|c|c|c|c|c|c|c|c|c|c|c|c|c|c|}
\hline \multirow[b]{2}{*}{ Tissue } & \multirow[b]{2}{*}{ Diet } & \multicolumn{2}{|c|}{ LA } & \multicolumn{2}{|c|}{$\mathrm{AA}$} & \multicolumn{2}{|c|}{ Sum n-6 } & \multicolumn{2}{|c|}{ EPA } & \multicolumn{2}{|c|}{$\mathrm{DHA}$} & \multicolumn{2}{|c|}{ Sum $n-3$} & \multicolumn{2}{|c|}{ n-6 HUFA† } \\
\hline & & Mean & SEM & Mean & SEM & Mean & SEM & Mean & SEM & Mean & SEM & Mean & SEM & Mean & SEM \\
\hline \multirow[t]{2}{*}{ Fillet $\neq(\mathrm{mg} / \mathrm{g})$} & $\mathrm{FO}$ & $3 \cdot 9^{*}$ & 0.3 & $0.5^{\star}$ & 0.0 & $5 \cdot 2^{\star}$ & 0.4 & $6 \cdot 5^{\star}$ & 0.2 & $11 \cdot 2^{*}$ & 0.8 & $24 \cdot 1^{*}$ & $1 \cdot 3$ & $5^{\star}$ & 0 \\
\hline & SO & $24 \cdot 6$ & $5 \cdot 0$ & 0.3 & 0.0 & $27 \cdot 7$ & $5 \cdot 7$ & 1.9 & 0.1 & $4 . \overline{9}$ & 0.4 & $11 \cdot 3$ & 0.9 & 23 & 4 \\
\hline \multirow[t]{2}{*}{ Liver§ (mg/g) } & $\mathrm{FO}$ & $0.5^{\star \star}$ & 0.0 & $0.9^{* *}$ & 0.0 & $1 \cdot 6^{*}$ & 0.0 & $3 \cdot 4^{* *}$ & 0.2 & $9 \cdot 2^{*}$ & 0.1 & $14 \cdot 0^{\star \star}$ & 0.2 & $7^{\star}$ & 0 \\
\hline & SO & 9.5 & $1 \cdot 4$ & 1.7 & 0.1 & 14.5 & 0.0 & 1.4 & 0.0 & $5 \cdot 8$ & 0.1 & $8 \cdot 6$ & 0.2 & 39 & 1 \\
\hline
\end{tabular}

LA, linoleic acid; AA, arachidonic acid; HUFA, highly unsaturated fatty acids.

Mean values were significantly different from those of SO-fed salmon: ${ }^{\star} P<0.04,{ }^{\star *} P<0.01$.

$\dagger n-6$ HUFA is calculated from the Lands equation ${ }^{(4)}:(20: 3 n-6+20: 4 n-6+22: 5 n-6) /(20: 3 n-6+20: 4 n-6+22: 5 n-6+20: 5 n-3+22: 5 n-3+22: 6 n-3) \times 100$

$\ddagger$ Pooled samples; three fish from three tanks.

§ Pooled samples; six fish from three tanks; $n 3$. 
leptin, adiponectin and insulin did not differ between the dietary treatments (Table 5).

Replacing FO with SO in feed for Atlantic salmon significantly lowered EPA and DHA in mice liver-PL, erythrocytePL and total lipids of eWAT, thereby decreasing the omega-3
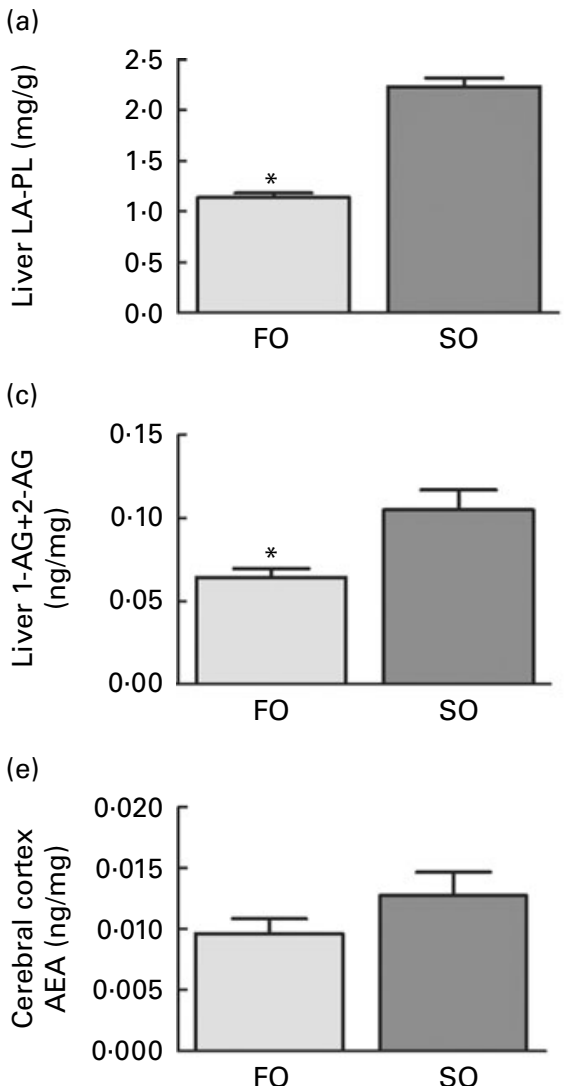

(g)

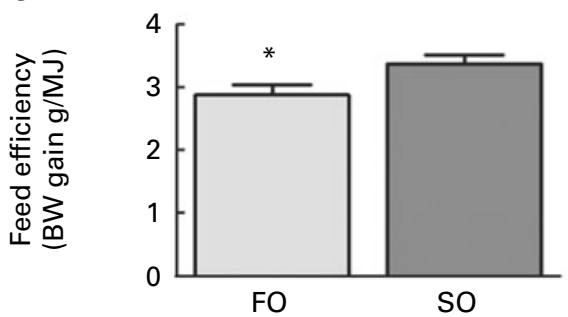

(i)

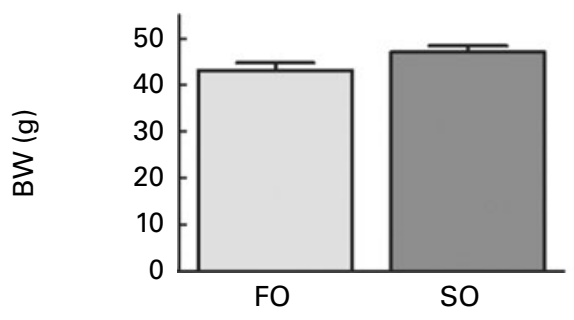

index from 23 to 16 and increasing n-6 highly unsaturated fatty acids from 19 to $39 \%$ (Table 4 ).

Adipose tissue accumulation and the adiposity index did not differ between mice fed the SO and FO salmon diets (Table 5). Staining eWAT and iWAT for the macrophage

(b)

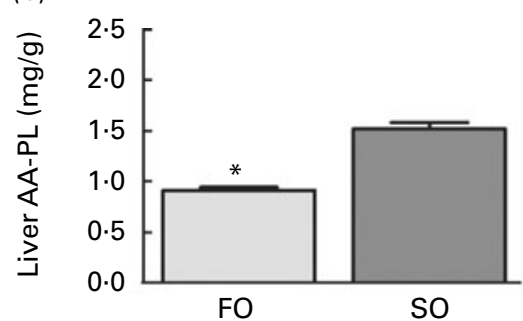

(d)

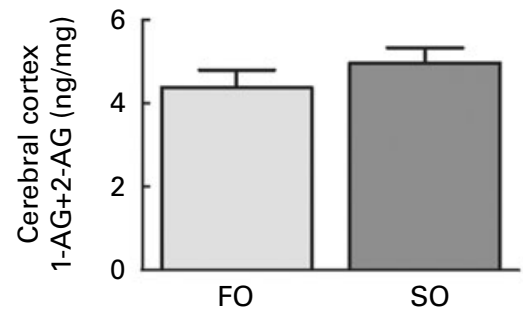

(f)

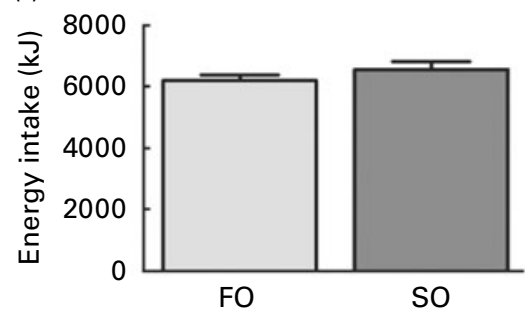

(h)

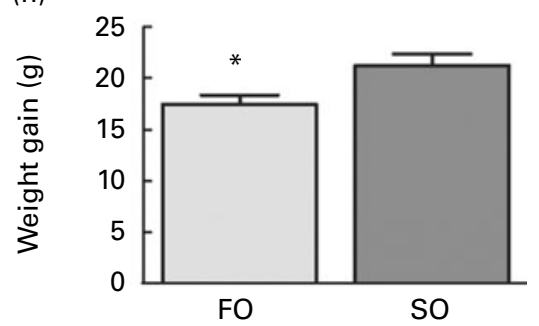

(j)

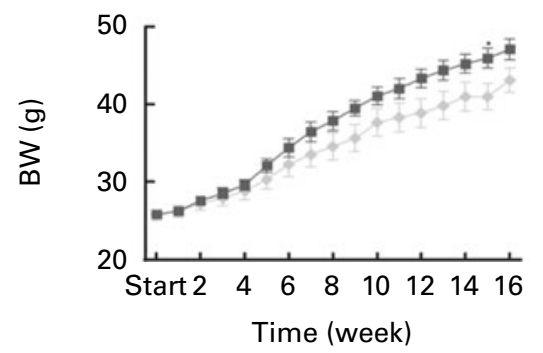

Fig. 2. Changes in (a) linoleic acid (LA), (b) arachidonic acid (AA) in liver phospholipids (PL), (c) liver 2-arachidonoylglycerol (AG), cerebral (d) 2-AG and (e) anandamide (AEA), and (f) energy intake, ( $g$ ) feed efficiency, (h) weight gain, (i) final body weight and (j) weekly body weight in mice fed the fish oil (FO, $\square$ ) and soyabean oil $(\mathrm{SO}, \square)$ salmon diets. Values are means, with their standard errors represented by vertical bars $(n 8-9) .{ }^{*}$ Mean values were significantly different from those of SO salmon-fed mice $(P<0.05)$. BW, body weight. 
Table 4. $n-6$ and $n-3$ profile of erythrocyte and liver phospholipids, and neutral lipids of epididymal white adipose tissue (eWAT) in mice fed fish oil (FO) and soyabean oil (SO) salmon

(Mean values with their standard errors, $n$ 9)

\begin{tabular}{|c|c|c|c|c|c|c|c|c|c|c|c|c|c|c|c|}
\hline \multirow[b]{2}{*}{ Tissue } & \multirow[b]{2}{*}{ Diet } & \multicolumn{2}{|c|}{ LA } & \multicolumn{2}{|c|}{ AA } & \multicolumn{2}{|c|}{ Sum $n-6$} & \multicolumn{2}{|c|}{ EPA } & \multicolumn{2}{|c|}{ DHA } & \multicolumn{2}{|c|}{ Sum $n-3$} & \multicolumn{2}{|c|}{$n-6$ HUFA† } \\
\hline & & Mean & SEM & Mean & SEM & Mean & SEM & Mean & SEM & Mean & SEM & Mean & SEM & Mean & SEM \\
\hline \multirow[t]{2}{*}{ Erythrocytes $(\mu \mathrm{g} / \mathrm{mg})$} & FO & $136^{\star \star \star}$ & 6 & $100^{\star \star \star}$ & 4 & $264^{\star \star \star}$ & 9 & $189^{\star \star \star}$ & 8 & $304^{*}$ & 12 & $550^{\star \star \star}$ & 19 & $19^{\star \star \star}$ & 0 \\
\hline & so & 297 & 9 & 177 & 8 & 563 & 19 & 99 & 2 & 270 & 7 & 413 & 10 & 39 & 1 \\
\hline \multirow[t]{2}{*}{ Liver (mg/g) } & FO & $1 \cdot 1^{* * *}$ & 0.1 & $0.8^{\star * *}$ & 0.0 & $2 \cdot 2^{\star \star \star}$ & 0.1 & $1 \cdot 5^{\star \star \star}$ & 0.0 & $4 \cdot 5^{\star \star \star}$ & 0.2 & $6 \cdot 3^{\star \star \star}$ & 0.3 & $14^{\star \star \star}$ & 0 \\
\hline & so & $2 \cdot 3$ & 0.1 & 1.5 & 0.1 & 4.3 & 0.1 & 0.8 & 0.1 & $2 \cdot 7$ & 0.1 & 3.7 & 0.2 & 37 & 2 \\
\hline \multirow[t]{2}{*}{ eWAT (mg/g) } & FO & $68^{\star \star \star}$ & 2 & $1 \cdot 3$ & 0.1 & $72^{\star \star \star}$ & 2 & $4 \cdot 5^{\star \star}$ & 0.8 & $14^{\star \star}$ & 2 & $38^{*}$ & 4 & $12^{\star \star \star}$ & 1 \\
\hline & so & 208 & 3 & 1.3 & 0.1 & 217 & 3 & 1.8 & 0.3 & 6 & 1 & 23 & 3 & 44 & 0 \\
\hline
\end{tabular}

LA, linoleic acid; AA, arachidonic acid; HUFA, highly unsaturated fatty acids.

Mean values were significantly different from those of SO salmon-fed mice: ${ }^{\star} P<0.03,{ }^{\star \star} P<0.01,{ }^{\star \star \star} P<0.0001$.

t $n-6$ HUFA is calculated from the Lands equation ${ }^{(4)}:(20: 3 n-6+20: 4 n-6+22: 5 n-6) /(20: 3 n-6+20: 4 n-6+22: 5 n-6+20: 5 n-3+22: 5 n-3+22: 6 n-3) \times 100$

marker F4/80 showed considerably more F4/80-positive macrophages forming crown-like structures around adipocytes in mice fed the SO salmon diet than mice fed the FO salmon diet (Fig. 3). The SO salmon diet containing $8 \mathrm{en} \%$ LA resulted in larger adipocyte size in iWAT, but not in eWAT, than the FO salmon diet containing 1 en\% LA (Fig. 3).

\section{Discussion}

Human consumption of soyabean oil has increased from $2 \cdot 2$ to $7 \cdot 3 \mathrm{en} \%$ at the same time as the intake of EPA and DHA declined in the USA during the twentieth century ${ }^{(3)}$. Increasing intake of LA has been linked to obesity in both humans $^{(10,19,21,51)}$ and rodents ${ }^{(7,10,18,19,23,52-54)}$. In the present study, we found that mice fed the SO salmon diet with a high level of LA ( $8 \mathrm{en} \%$ ) had higher liver concentrations of AA-PL and 2-AG. The elevated endocannabinoid activity in mice fed the SO salmon diet was associated with increased feed efficiency, higher weight gain and body weight $(P<0.8)$ compared with mice fed the FO salmon diet. We have previously shown that elevating dietary LA from 1 to $8 \mathrm{en} \%$ increases endocannabinoid production and induces obesity in mice fed high-fat diets, an effect that was reduced by adding 1 en\% EPA and DHA to $8 \mathrm{en} \%$ LA diets ${ }^{(10)}$. The present and our previous findings are consistent with several reports that show how dietary fat alters endocannabinoid levels ${ }^{(5,6,11-14,20,55)}$.

The findings of lower weight gain and body weight in mice fed the FO salmon diet compared with mice fed the SO salmon diet are in line with the general notion that fish oil rich in EPA and DHA limits high-fat diet-induced obesity in rodents $^{(26,27)}$, an effect that is associated with reduced tissue levels of AA-PL ${ }^{(22)}$. The diet based on SO-enriched salmon resulted in larger adipocyte size in iWAT and more macrophage infiltration in eWAT than the FO-fed salmon diet. Diets enriched with $n-3$ PUFA have been demonstrated to reduce adipose tissue inflammation in diet-induced obesity ${ }^{(56-58)}$. The mechanism by which EPA and DHA reduce macrophage-induced adipose tissue inflammation has recently been demonstrated to be mediated by the stimulation of the fatty acid receptor GPR120 ${ }^{(59)}$. EPA and DHA can be converted to metabolic products such as resolvins and protectins with anti-inflammatory actions independent of the state of obesity $^{(60)}$. Although both salmon diets contained relatively high amounts of EPA and DHA, the present data suggest that dietary LA of $8 \mathrm{en} \%$ decrease the anti-inflammatory properties of EPA and DHA. In keeping with the recent finding that sucrose counteracts the anti-inflammatory effect of fish oil in adipose tissue $^{(61)}$, these data demonstrate that the background diet influences the anti-inflammatory properties of EPA and DHA.

Traditionally, farmed Atlantic salmon have consumed diets high in EPA and DHA and low in LA and $\alpha$-linolenic acid. Introducing vegetable oils in farmed fish feed has altered the dietary fatty acid profile and fillet fatty acid composition ${ }^{(45)}$ Consistent with prior reports ${ }^{(44-46)}$, replacing fish oil with soyabean oil in feed for Atlantic salmon increased dietary LA from 1.5 to $21 \mathrm{en} \%$ in feed, and altered the fatty acid profile of salmon fillet and liver by increasing LA and decreasing EPA and DHA after 6 months of feeding. To our knowledge, we are the first to show that dietary LA from soyabean oil elevated 2-AG in the salmon liver. Consistent with previous reports

Table 5. Physical and biochemical parameters in mice fed fish oil (FO) or soyabean oil (SO) salmon†‡

(Mean values with their standard errors)

\begin{tabular}{|c|c|c|c|c|}
\hline \multirow[b]{2}{*}{ Parameters } & \multicolumn{2}{|c|}{ FO } & \multicolumn{2}{|c|}{ SO } \\
\hline & Mean & SEM & Mean & SEM \\
\hline Total food intake $(g / 112 d)$ & 330 & 10 & 347 & 13 \\
\hline Initial body weight (g) & $25 \cdot 7$ & 0.8 & $25 \cdot 8$ & 0.5 \\
\hline Final body weight (g) & $43 \cdot 1$ & 1.6 & $47 \cdot 1$ & 1.3 \\
\hline Liver weight $(\mathrm{g})$ & $1 \cdot 7^{\star}$ & 0.2 & $2 \cdot 3$ & 0.2 \\
\hline iWAT $(\mathrm{g})$ & 0.7 & 0.1 & 0.9 & 0.1 \\
\hline eWAT (g) & 1.9 & 1.9 & 1.8 & 0.1 \\
\hline rWAT (g) & 0.8 & 0.1 & 0.9 & 0.1 \\
\hline Adiposity index§ (\%) & $9 \cdot 7$ & 0.6 & $10 \cdot 0$ & 0.6 \\
\hline Leptin & $17 \cdot 0$ & $2 \cdot 0$ & $19 \cdot 0$ & $2 \cdot 1$ \\
\hline Adiponectin & 2.9 & 0.3 & $3 \cdot 1$ & 0.2 \\
\hline Insulin & 8.8 & 0.7 & $9 \cdot 0$ & 0.2 \\
\hline
\end{tabular}

iWAT, inguinal white adipose tissue; eWAT, epididymal white adipose tissue; rWAT, retroperitoneal white adipose tissue.

${ }^{*}$ Mean value was significantly different from that of SO salmon-fed mice $(P<0.04)$. † $n 9$ for food and energy intake, feed efficiency and body weight; $n 6-7$ for hormone levels.

‡Feed efficiency: (body weight gain (g)/energy (MJ) intake).

$\S$ Adiposity index: ((epididymal fat + inguinal fat + retroperitoneal fat $) /$ eviscerated body weight) $\times 100$. 
(a)

$\mathrm{F} 4 / 80$

immunostaining

FO

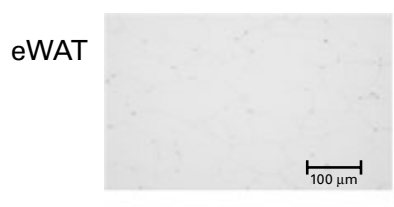

iWAT

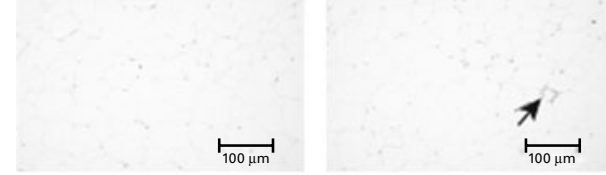

(b)

SO
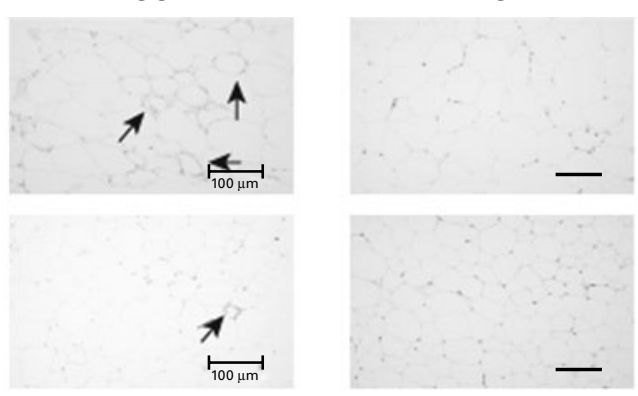

so

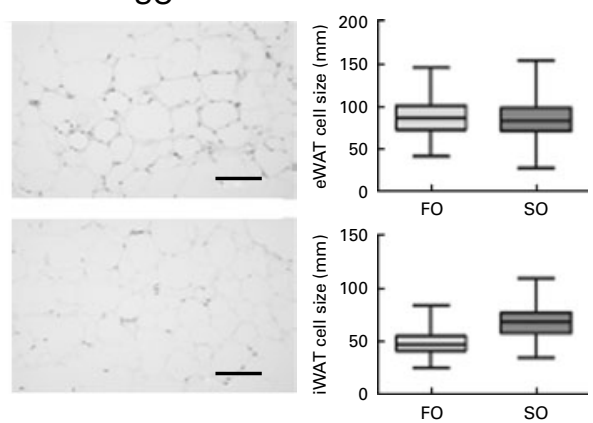

Fig. 3. Histology of epididymal white adipose tissue (eWAT) and inguinal white adipose tissue (iWAT) in mice fed the fish oil (FO) and soyabean oil (SO) salmon diets. (a) Immunostaining with the macrophage marker F4/80 in eWAT and iWAT of FO- and SO-fed mice. (b) Haematoxylin eosin (HE) staining and adipocyte size in eWAT and iWAT of mice fed the FO and SO salmon diets. Values are means, minimum and maximum ranges represented by vertical bars.

replacing fish oil with soyabean oil ${ }^{(62)}$ or a blend of vegetable oils ${ }^{(63-65)}$, we found that Atlantic salmon fed soyabean oil accumulated significantly more TAG and total lipids in the liver than salmon fed fish oil. Liver is the main source of de novo fatty acid synthesis, and the activation of liver cannabinoid receptor 1 stimulates de novo fatty acid synthesis in mice by increasing the activity of the transcription factor sterol regulatory element binding protein-1c (SREBP-1c), and its target enzymes fatty acid synthase and acetyl-CoA carboxylase ${ }^{(8)}$. Recent studies have demonstrated that replacing fish oil with vegetable oil in Atlantic salmon up-regulated the expression of SREBP-1c and fatty acid synthase in the salmon liver ${ }^{(66)}$, affecting pathways of cholesterol and lipoprotein metabolism ${ }^{(65)}$. It is therefore likely that an elevated endocannabinoid tone in the liver of salmon fed soyabean oil may have stimulated the hepatic de novo synthesis of fatty acids. In Atlantic salmon, replacing fishmeal and fish oil with high levels of plant protein (80\%) and a vegetable oil blend (70\%) of rapeseed, palm and linseed oil increased whole-body lipids, the visceral somatic index and liver lipid stores after 12 months of feeding ${ }^{(63)}$ concomitant with a significant lower body weight ${ }^{(67)}$. In another study, replacing fish oil with a vegetable oil blend (rapeseed, palm and linseed oil) increased body weight in Atlantic salmon receiving vegetable oil compared with fish oil possibly due to the long-term effects increasing nutrient utilisation ${ }^{(44)}$. We did not find any effect on body weight or the visceral somatic index in salmon when soyabean oil replaced fish oil for 6 months, indicating interacting effects between oil source and protein source, or length of feeding required to affect body weights or visceral fat stores in Atlantic salmon ${ }^{(44,63)}$.

There have been increasing concerns about the decreasing content of EPA and DHA in farmed Atlantic salmon. Norwegian surveillance data ${ }^{(68)}$ report a moderate increase in LA levels in the fillets of farmed Atlantic salmon from $1.1 \mathrm{~g} / 100 \mathrm{~g}$ in 2005 to $1.6 \mathrm{~g} / 100 \mathrm{~g}$ in 2010 and a decrease in $\mathrm{EPA}+\mathrm{DHA}$ from $2 \cdot 7 \mathrm{~g} / 100 \mathrm{~g}$ to $2 \cdot 1 \mathrm{~g} / 100 \mathrm{~g}$ in the same period. In the present study, Atlantic salmon was fed soyabean oil, a major dietary source of LA, resulting in $2.5 \mathrm{~g}$ LA and $0.7 \mathrm{~g}$
$\mathrm{EPA}+\mathrm{DHA} / 100 \mathrm{~g}$ fillet, representing an extreme model where vegetable oils replace fish oil in feed for Atlantic salmon. Although recognised as suitable alternatives to fish oil in feed for Atlantic salmon, the present findings of elevated liver endocannabinoid and lipid accumulation in salmon fed soyabean oil suggest that future fish oil replacement in farmed Atlantic salmon should pay attention to the choice of vegetable oils with regard to LA content. However, although lower than the FO salmon diet, mice fed the SO salmon diet for 16 weeks had a high omega- 3 index and low $n-6$ highly unsaturated fatty acids (16 and 39\%, respectively), indicating that farmed Atlantic salmon fed vegetable oil remain a significant dietary source of EPA and DHA.

In summary, replacing fish oil with soyabean oil in feed for Atlantic salmon introduces high dietary levels of LA in Atlantic salmon and elevates AA, endocannabinoid activity and TAG accumulation in the salmon liver. Mice consuming Atlantic salmon fed soyabean oil have higher liver levels of AA-PL and 2-AG, higher feed efficiency, higher weight gain and more adipose tissue inflammation than mice fed the FO salmon diet. Thus, lower dietary levels of LA may improve metabolic functions associated with obesity.

\section{Supplementary material}

To view supplementary material for this article, please visit http://dx.doi.org/10.1017/S0007114512003364

\section{Acknowledgements}

The present study was supported by the National Institute of Nutrition and Seafood Research, Bergen, Norway, the Intramural Research Program of the National Institute on Alcohol Abuse and Alcoholism, National Institutes of Health, USA, and the Research Council of Norway 186908/110. The authors' responsibilities were as follows: A. R. A. and M. K. M. designed the study and conducted the mouse trial. A. R. A., Y. H. L., E.-J. L. and H. H. L. analysed the data. A. R. A. performed the statistical analysis and had primary responsibility for the final content; 
B. E. T. designed the study and conducted the fish trial. A. R. A., L. M. and B. E. T. wrote the paper; J. R. H. contributed to the design and provided the essential equipment. The authors declare that they have no conflict of interest.

\section{References}

1. Harris WS, Mozaffarian D, Rimm E, et al. (2009) Omega-6 fatty acids and risk for cardiovascular disease: a science advisory from the American Heart Association Nutrition Subcommittee of the Council on Nutrition, Physical Activity, and Metabolism; Council on Cardiovascular Nursing; and Council on Epidemiology and Prevention. Circulation 119, 902-907.

2. Mozaffarian D, Micha R \& Wallace S (2010) Effects on coronary heart disease of increasing polyunsaturated fat in place of saturated fat: a systematic review and meta-analysis of randomized controlled trials. PLoS Med 7, e1000252.

3. Blasbalg TL, Hibbeln JR, Ramsden CE, et al. (2011) Changes in consumption of omega- 3 and omega- 6 fatty acids in the United States during the 20th century. Am J Clin Nutr 93, 950-962.

4. Lands WE, Libelt B, Morris A, et al. (1992) Maintenance of lower proportions of $(n-6)$ eicosanoid precursors in phospholipids of human plasma in response to added dietary (n-3) fatty acids. Biochim Biophys Acta 1180, 147-162.

5. Artmann A, Petersen G, Hellgren LI, et al. (2008) Influence of dietary fatty acids on endocannabinoid and $\mathrm{N}$-acylethanolamine levels in rat brain, liver and small intestine. Biochim Biophys Acta 1781, 200-212.

6. Wood JT, Williams JS, Pandarinathan L, et al. (2010) Dietary docosahexaenoic acid supplementation alters select physiological endocannabinoid-system metabolites in brain and plasma. J Lipid Res 51, 1416-1423.

7. Matias I, Petrosino S, Racioppi A, et al. (2008) Dysregulation of peripheral endocannabinoid levels in hyperglycemia and obesity: effect of high fat diets. Mol Cell Endocrinol 286, S66-S78.

8. Osei-Hyiaman D, DePetrillo M, Pacher P, et al. (2005) Endocannabinoid activation at hepatic CB1 receptors stimulates fatty acid synthesis and contributes to diet-induced obesity. J Clin Invest 115, 1298-1305.

9. Starowicz KM, Cristino L, Matias I, et al. (2008) Endocannabinoid dysregulation in the pancreas and adipose tissue of mice fed with a high-fat diet. Obesity 16, 553-565.

10. Alvheim AR, Malde MK, Osei-Hyiaman D, et al. (2012) Dietary linoleic acid elevates endogenous 2-AG and anandamide and induces obesity. Obesity (Silver Spring) (epublication ahead of print version 15 February 2012).

11. Berger A, Crozier G, Bisogno T, et al. (2001) Anandamide and diet: inclusion of dietary arachidonate and docosahexaenoate leads to increased brain levels of the corresponding $\mathrm{N}$-acylethanolamines in piglets. Proc Natl Acad Sci U S A $\mathbf{9 8 ,}$ 6402-6406.

12. Di Marzo V, Griinari M, Carta G, et al. (2010) Dietary krill oil increases docosahexaenoic acid and reduces 2-arachidonoylglycerol but not $N$-acylethanolamine levels in the brain of obese Zucker rats. Int Dairy J 20, 231-235.

13. Piscitelli F, Carta G, Bisogno T, et al. (2011) Effect of dietary krill oil supplementation on the endocannabinoidome of metabolically relevant tissues from high-fat-fed mice. Nutr Metab 8, 51-67.

14. Watanabe S, Doshi M \& Hamazaki T (2003) n-3 Polyunsaturated fatty acid (PUFA) deficiency elevates and n-3 PUFA enrichment reduces brain 2-arachidonoylglycerol level in mice. Prostaglandins Leukot Essent Fatty Acids 69, 51-59.

15. Batetta B, Griinari M, Carta G, et al. (2009) Endocannabinoids may mediate the ability of $(n-3)$ fatty acids to reduce ectopic fat and inflammatory mediators in obese Zucker rats. J Nutr 139, 1495-1501.

16. Cota D, Marsicano G, Tschop M, et al. (2003) The endogenous cannabinoid system affects energy balance via central orexigenic drive and peripheral lipogenesis. J Clin Invest 112, 423-431.

17. Ailhaud G, Guesnet P \& Cunnane SC (2008) An emerging risk factor for obesity: does disequilibrium of polyunsaturated fatty acid metabolism contribute to excessive adipose tissue development? Br J Nutr 100, 461-470.

18. Madsen L, Pedersen LM, Liaset B, et al. (2008) cAMP-dependent signaling regulates the adipogenic effect of $n$ - 6 polyunsaturated fatty acids. J Biol Chem 283, 7196-7205.

19. Massiera F, Saint-Marc P, Seydoux J, et al. (2003) Arachidonic acid and prostacyclin signaling promote adipose tissue development: a human health concern? J Lipid Res $4 \mathbf{4}$, 271-279.

20. Matias I, Carta G, Murru E, et al. (2008) Effect of polyunsaturated fatty acids on endocannabinoid and $N$-acyl-ethanolamine levels in mouse adipocytes. Biochim Biophys Acta 1781, 52-60.

21. Dayton S, Hashimoto S, Dixon W, et al. (1966) Composition of lipids in human serum and adipose tissue during prolonged feeding of a diet high in unsaturated fat. J Lipid Res 7, 103-111.

22. Cunnane SC, Manku MS \& Horrobin DF (1985) Essential fatty acids in the liver and adipose tissue of genetically obese mice: effect of supplemental linoleic and gamma-linolenic acids. Br J Nutr 53, 441-448.

23. Ikemoto S, Takahashi M, Tsunoda N, et al. (1996) High-fat diet-induced hyperglycemia and obesity in mice: differential effects of dietary oils. Metabolism 45, 1539-1546.

24. Massiera F, Barbry P, Guesnet P, et al. (2010) A Western-like fat diet is sufficient to induce a gradual enhancement in fat mass over generations. J Lipid Res 51, 2352-2361.

25. Okuno M, Kajiwara K, Imai S, et al. (1997) Perilla oil prevents the excessive growth of visceral adipose tissue in rats by down-regulating adipocyte differentiation. J Nutr 127, $1752-1757$.

26. Belzung F, Raclot $\mathrm{T}$ \& Groscolas R (1993) Fish oil $n$-3 fatty acids selectively limit the hypertrophy of abdominal fat depots in growing rats fed high-fat diets. Am J Physiol 264, R1111-R1118.

27. Hill JO, Peters JC, Lin D, et al. (1993) Lipid accumulation and body fat distribution is influenced by type of dietary fat fed to rats. Int J Obes Relat Metab Disord 17, 223-236.

28. Kunesova M, Braunerova R, Hlavaty P, et al. (2006) The influence of $n-3$ polyunsaturated fatty acids and very low calorie diet during a short-term weight reducing regimen on weight loss and serum fatty acid composition in severely obese women. Physiol Res 55, 63-72.

29. Mori T, Kondo H, Hase T, et al. (2007) Dietary fish oil upregulates intestinal lipid metabolism and reduces body weight gain in C57BL/6J mice. J Nutr 137, 2629-2634.

30. Thorsdottir I, Tomasson H, Gunnarsdottir I, et al. (2007) Randomized trial of weight-loss-diets for young adults varying in fish and fish oil content. Int J Obes (Lond) 31, 1560-1566.

31. Despres JP (2007) The endocannabinoid system: a new target for the regulation of energy balance and metabolism. Crit Pathw Cardiol 6, 46-50.

32. Van Gaal LF, Rissanen AM, Scheen AJ, et al. (2005) Effects of the cannabinoid-1 receptor blocker rimonabant on weight 
reduction and cardiovascular risk factors in overweight patients: 1-year experience from the RIO-Europe study. Lancet 365, 1389-1397.

33. Christensen R, Kristensen PK, Bartels EM, et al. (2007) Efficacy and safety of the weight-loss drug rimonabant: a meta-analysis of randomised trials. Lancet 370, 1706-1713.

34. Christopoulou FD \& Kiortsis DN (2011) An overview of the metabolic effects of rimonabant in randomized controlled trials: potential for other cannabinoid 1 receptor blockers in obesity. J Clin Pharm Ther 36, 10-18.

35. Elphick MR \& Egertova M (2001) The neurobiology and evolution of cannabinoid signalling. Philos Trans $R$ Soc Lond B Biol Sci 356, 381-408.

36. De Petrocellis L, Melck D, Bisogno T, et al. (1999) Finding of the endocannabinoid signalling system in Hydra, a very primitive organism: possible role in the feeding response. Neuroscience 92, 377-387.

37. Soderstrom K, Tian Q, Valenti M, et al. (2004) Endocannabinoids link feeding state and auditory perception-related gene expression. J Neurosci 24, 10013-10021.

38. Valenti M, Cottone E, Martinez R, et al. (2005) The endocannabinoid system in the brain of Carassius auratus and its possible role in the control of food intake. $J$ Neurochem 95, 662-672.

39. Yamaguchi F, Macrae AD \& Brenner S (1996) Molecular cloning of two cannabinoid type 1-like receptor genes from the puffer fish Fugu rubripes. Genomics 35, 603-605.

40. Sepe N, De Petrocellis L, Montanaro F, et al. (1998) Bioactive long chain $\mathrm{N}$-acylethanolamines in five species of edible bivalve molluscs. Possible implications for mollusc physiology and sea food industry. Biochim Biophys Acta 1389, $101-111$

41. Kirkham TC, Williams CM, Fezza F, et al. (2002) Endocannabinoid levels in rat limbic forebrain and hypothalamus in relation to fasting, feeding and satiation: stimulation of eating by 2-arachidonoyl glycerol. $\mathrm{Br} J$ Pharmacol 136, 550-557.

42. Piccinetti CC, Migliarini B, Petrosino S, et al. (2010) Anandamide and AM251, via water, modulate food intake at central and peripheral level in fish. Gen Comp Endocrinol 166, 259-267.

43. Tacon AGJ, Hasan MR \& Subasinghe RP (2006) Use of fishery resources as feed inputs for aquaculture development: trends and policy implications. In FAO Fish Circ no. 1018, p. 99 Rome: FAO.

44. Torstensen BE, Bell JG, Rosenlund G, et al. (2005) Tailoring of Atlantic salmon (Salmo salar L.) flesh lipid composition and sensory quality by replacing fish oil with a vegetable oil blend. J Agric Food Chem 53, 10166-10178.

45. Turchini GM, Torstensen BT \& Ng WK (2009) Fish oil replacement in finfish nutrition. Rev Aquacult 1, 10-57.

46. Grisdale-Helland B, Ruyter B, Rosenlund G, et al. (2002) Influence of high contents of dietary soybean oil on growth, feed utilization, tissue fatty acid composition, heart histology and standard oxygen consumption of Atlantic salmon (Salmo salar) raised at two temperatures. Aquaculture 207, 311-329.

47. Lie O \& Lambertsen G (1991) Fatty-acid composition of glycerophospholipids in seven tissues of cod (Gadus morbua), determined by combined high-performance liquid-chromatography and gas-chromatography. J Chromatogr $\mathbf{5 6 5}$, 119-129.

48. Torstensen BE, Nanton DA, Olsvik PA, et al. (2009) Gene expression of fatty acid-binding proteins, fatty acid transport proteins (cd36 and FATP) and beta-oxidation-related genes in Atlantic salmon (Salmo salar L.) fed fish oil or vegetable oil. Aquacult Nutr 15, 440-451.

49. Jordal A-EO, Lie $\varnothing$ \& Torstensen BE (2007) Complete replacement of dietary fish oil with a vegetable oil blend affect liver lipid and plasma lipoprotein levels in Atlantic salmon (Salmo salar L.). Aqua Nutr 13, 114-130.

50. Bell JG, Dick JR, Mc Vicar AH, et al. (1993) Dietary sunflower, linseed and fish oils affect phospholipid fatty acid composition, development of cardiac lesions, phospholipase activity and eicosanoid production in Atlantic salmon. Prostaglandins Leukot Essent Fatty Acids 49, 665-673.

51. Ailhaud G, Massiera F, Weill P, et al. (2006) Temporal changes in dietary fats: role of $n-6$ polyunsaturated fatty acids in excessive adipose tissue development and relationship to obesity. Prog Lipid Res 45, 203-236.

52. Javadi M, Everts H, Hovenier R, et al. (2004) The effect of six different C18 fatty acids on body fat and energy metabolism in mice. Br J Nutr 92, 391-399.

53. Pellizzon M, Buison A, Ordiz F, et al. (2002) Effects of dietary fatty acids and exercise on body-weight regulation and metabolism in rats. Obes Res 10, 947-955.

54. Takahashi Y \& Ide T (2000) Dietary $n$-3 fatty acids affect mRNA level of brown adipose tissue uncoupling protein 1 , and white adipose tissue leptin and glucose transporter 4 in the rat. Br J Nutr 84, 175-184.

55. Banni S, Carta G, Murru E, et al. (2011) Krill oil significantly decreases 2-arachidonoylglycerol plasma levels in obese subjects. Nutr Metab (Lond) 8, 7-13.

56. Huber J, Loffler M, Bilban M, et al. (2007) Prevention of highfat diet-induced adipose tissue remodeling in obese diabetic mice by $n-3$ polyunsaturated fatty acids. Int $J$ Obes (Lond) 31, 1004-1013.

57. Perez-Echarri N, Perez-Matute $\mathrm{P}$, Marcos-Gomez B, et al. (2008) Differential inflammatory status in rats susceptible or resistant to diet-induced obesity: effects of EPA ethyl ester treatment. Eur J Nutr 47, 380-386.

58. Todoric J, Loffler M, Huber J, et al. (2006) Adipose tissue inflammation induced by high-fat diet in obese diabetic mice is prevented by $n-3$ polyunsaturated fatty acids. Diabetologia 49, 2109-2119.

59. Oh DY, Talukdar S, Bae EJ, et al. (2010) GPR120 is an omega-3 fatty acid receptor mediating potent anti-inflammatory and insulin-sensitizing effects. Cell 142, 687-698.

60. Bannenberg GL, Chiang N, Ariel A, et al. (2005) Molecular circuits of resolution: formation and actions of resolvins and protectins. J Immunol 174, 4345-4355.

61. Ma T, Liaset B, Hao Q, et al. (2011) Sucrose counteracts the anti-inflammatory effect of fish oil in adipose tissue and increases obesity development in mice. PLoS One 6, e21647.

62. Ruyter B, Moya-Falcon C, Rosenlund G, et al. (2006) Fat content and morphology of liver and intestine of Atlantic salmon (Salmo salar): effects of temperature and dietary soybean oil. Aquaculture 252, 441-452.

63. Torstensen BE, Espe M, Stubhaug I, et al. (2011) Dietary plant proteins and vegetable oil blends increase adiposity and plasma lipids in Atlantic salmon (Salmo salar L.). Br J Nutr 3, 1-15.

64. Torstensen BE, Jordal AEO \& Lie O (2007) Complete replacement of dietary fish oil with a vegetable oil blend affect liver lipid and plasma lipoprotein levels in Atlantic salmon (Salmo salar L.). Aquacult Nutr 13, 114-130.

65. Morais S, Pratoomyot J, Torstensen BE, et al. (2011) Diet $\times$ genotype interactions in hepatic cholesterol and lipoprotein metabolism in Atlantic salmon (Salmo salar) in response to replacement of dietary fish oil with vegetable oil. Br J Nutr 106, 1457-1469. 
66. Morais S, Pratoomyot J, Taggart JB, et al. (2011) Genotypespecific responses in Atlantic salmon (Salmo salar) subject to dietary fish oil replacement by vegetable oil: a liver transcriptomic analysis. BMC Genomics 12, 255-272.

67. Torstensen BE, Espe M, Sanden M, et al. (2008) Novel production of Atlantic salmon (Salmo salar) protein based on combined replacement of fish meal and fish oil with plant meal and vegetable oil blends. Aquaculture 285, 193-200.
68. NIFES (2011) Seafood data http://www.nifes.no/sjomatdata/ index.php?page_id=\&lang_id $=2$

69. Harris WS \& von Schacky C (2004) The Omega-3 Index: a new risk factor for death from coronary heart disease? Prev Med 39, 212-220.

70. Lands B (2009) Measuring blood fatty acids as a surrogate indicator for coronary heart disease risk in population studies. World Rev Nutr Diet 100, 22-34. 